\title{
The Use of Cultured Bone Marrow Cells for Autologous Transplantation in Patients with Acute Myeloblastic Leukemia
}

\author{
N.G. Testa ${ }^{1}$, L. Coutinho ${ }^{1}$, J. Chang ${ }^{2}$, G. Morgenstern ${ }^{2}$, J.H. Scarffe ${ }^{3}$, and T.M. \\ Dexter ${ }^{1}$
}

\section{A. Introduction}

The permissive or inductive environment provided by bone marrow stromal cells in long-term cultures allows the persistent proliferation and differentiation of haemopoietic stem and progenitor cells [1]. Cells harvested from cultures of murine bone marrow can reconstitute the haemopoietic system when transplanted into lethally irradiated mice [2]. If bone marrow heavily infiltrated with leukaemic cells is cultured using similar conditions, the leukaemic blast cells become undetectable within 1 week, and the cultured marrow can then be used to rescue

\footnotetext{
${ }^{1}$ Department of Experimental Haematology, Paterson Laboratories

${ }^{2}$ Department of Haematology

${ }^{3}$ Department of Medical Oncology, Christie Hospital and Holt Radium Institute, Manchester M20 9BX, England
}

lethally irradiated mice [3]. In cultures of bone marrow cells from untreated patients with chronic granulocytic leukaemia (CML), the Philadelphia chromosome decreased, after being present in over $95 \%$ of mitoses, to almost undetectable levels. In the same cultures, $\mathrm{Ph}$-negative cells became the predominant mitotic population [4]. Similarly, in some cultures established from bone marrow from patients with newly diagnosed acute myeloblastic leukaemia (AML), the size of the leukaemic clone (assessed either by chromosome markers or by a characteristic abnormal growth pattern in colony assays) diminished to undetectable levels, while normal haemopoiesis became dominant $([5,6]$ and our unpublished results). A similar pattern may also be seen in cultures established from bone marrow in relapse.

From these experimental data, summarized in Table 1, it would appear that the conditions prevailing in vitro may both suppress the growth of leukaemic cells and fa-

Table 1. Emergence of normal cells in long-term cultures of leukaemic bone marrow

\begin{tabular}{|c|c|c|c|}
\hline Bone marrow & Diagnosis & Parameters measured & Reference \\
\hline Murine & $\begin{array}{l}\text { Disseminated } \\
\text { thymoma }\end{array}$ & $\begin{array}{l}\text { Disappearance of blast cells } \\
\text { Ability to reconstitute the haemopoietic system } \\
\text { upon transplant }\end{array}$ & {$[3]$} \\
\hline \multirow[t]{2}{*}{ Human } & $\mathrm{CML}$ & $\begin{array}{l}\text { Disappearance of } \mathrm{Ph} \text { chromosome } \\
\text { Reappearance of } \mathrm{Ph} \text {-negative (normal?) mitosis }\end{array}$ & [4] \\
\hline & AML & $\begin{array}{l}\text { Disappearance of chromosome markers } \\
\text { Disappearance of leukaemic colony growth pattern } \\
\text { Appearance of normal colony growth pattern } \\
\text { Appearance of normal chromosome pattern }\end{array}$ & {$[5,6]$} \\
\hline
\end{tabular}


cilitate the regeneration of normal haemopoietic cells from the small numbers of normal progenitors still present in the leukaemic marrows. These observations led us to perform autologous bone marrow transplants (BMT), using cultured cells, in AML patients who were thought to be able to benefit from bone marrow transplantation and who had no HLA-matched donors.

\section{B. Methods}

Patient details are shown in Table 3. All patients had received three courses of combi- nation chemotherapy, each consisting of a 7day infusion of cytosine arabinoside, oral thioguanine and three injections of daunorubicin. Time elapsed from end of chemotherapy to bone marrow harvest is shown. Two patients were harvested early in first relapse without having received additional chemotherapy. Marrow was harvested under general anaesthetic and used to establish long-term cultures (Fig. 1). The protocol followed in the BMT is shown in Table 2. The patients were nursed in a laminar-flow tent, received prophylactic oral antimicrobials and a low-pathogen diet, prophylactic transfusions of irradiated platelets and irra-

Table 2. Timetable for autologous transplantation of cultured bone marrow

\begin{tabular}{|c|c|c|}
\hline Day & Patient protocol & Laboratory procedures \\
\hline & Bone marrow harvest & $\begin{array}{l}1 / 2 \text { for bone marrow culture (see Fig. 1) } \\
1 / 2 \text { cryopreserved }\end{array}$ \\
\hline $\left.\begin{array}{l}-5 \\
-4 \\
-2 \\
-1\end{array}\right\}$ & $\begin{array}{l}\text { Cyclophosphamide } \\
\left(2 \times 1.8 \mathrm{~g} / \mathrm{m}^{2}\right) \\
\text { Total body irradiation } \\
(6 \times 200 \mathrm{cGy})\end{array}$ & \\
\hline 0 & Infusion of cultured cells & Harvest of cultured cells (see Fig. 1) \\
\hline
\end{tabular}

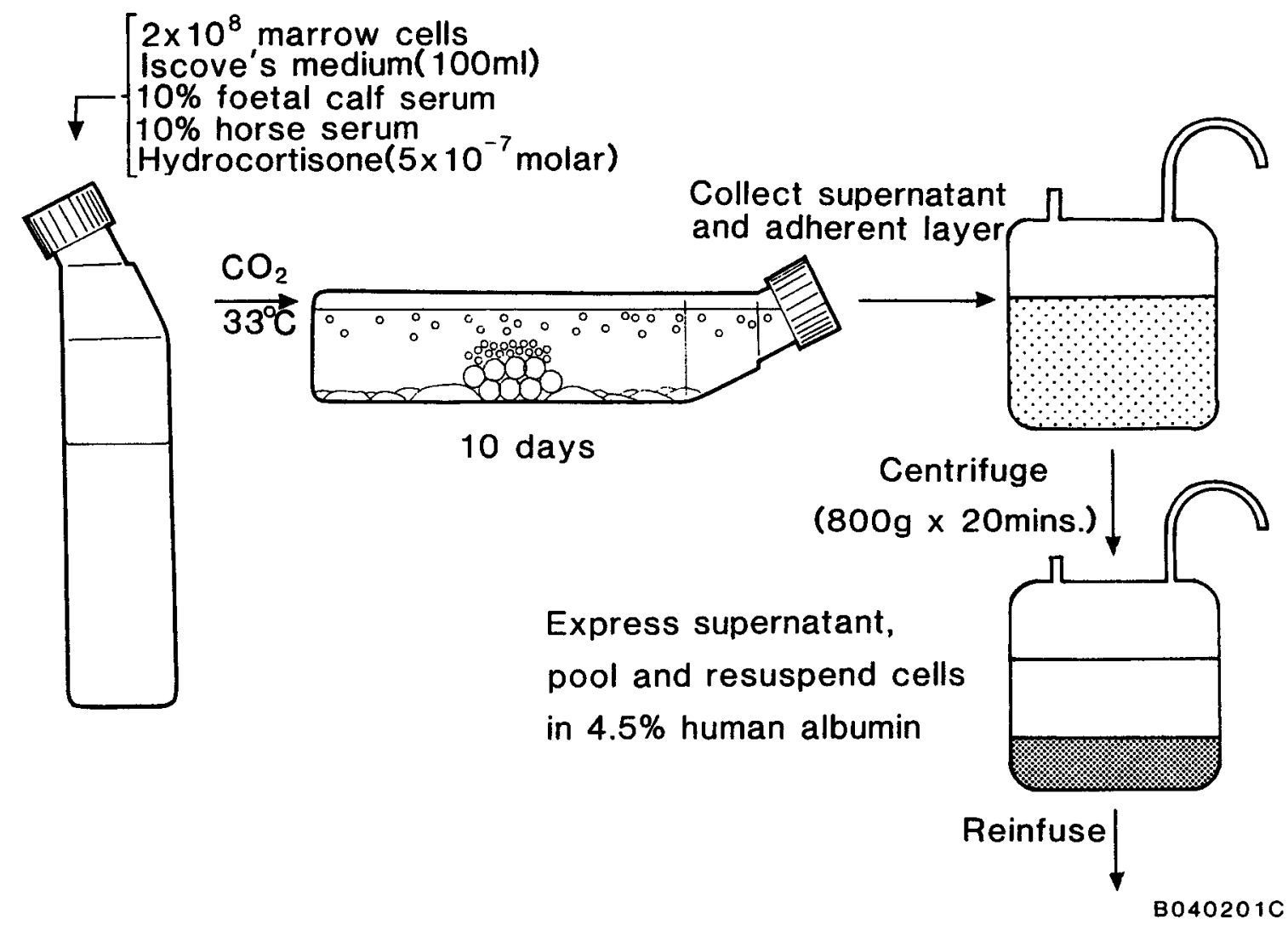

Fig. 1. Long-term bone marrow cultures for autologous transplantation; 40-70 replicate flasks are established from one-half of the bone marrow harvested (see Table 2) 


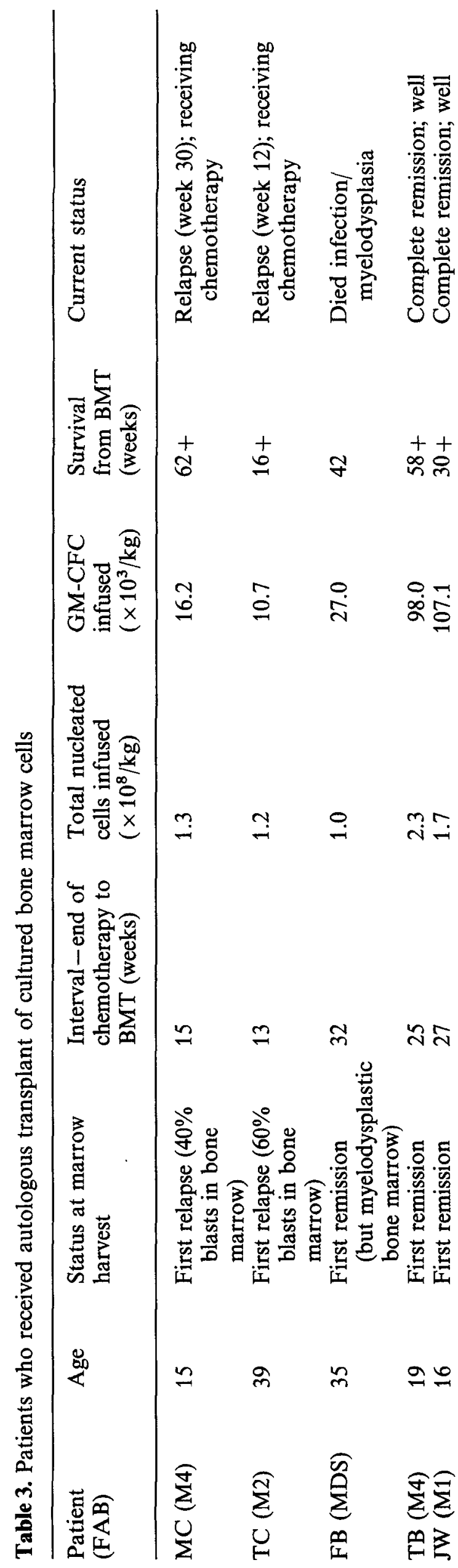

diated red-cell transfusions and systemic antimicrobials, as indicated.

\section{Results}

Details of BMT, haematological recovery and outcome are shown in Tables 3 and 4. The first patient was in early relapse at the time of marrow harvest. Serial cytogenetic studies performed during the preceding clinical remission had shown that the $16 \mathrm{q}$ abnormality which characterised his leukaemic clone had persisted in about onefifth of the mitoses from the bone marrow. However, only normal mitoses were detected after the bone marrow had been in culture for 7-14 days [6]. Following transplantation, full reconstitution was achieved, the $16 \mathrm{q}$ marker became undetectable (for the first time since diagnosis) and the patient entered a full remission. The second patient transplanted in relapse (without a chromosomal marker) regenerated leukaemia 12 weeks after BMT. He continue sin good clinical condition, leading an active life on haematological support.

One patient transplanted in remission following chemotherapy for transformation of a myelodysplastic syndrome reverted not to normal haemopoiesis, but to myelodysplasia after the transplant. She required support transfusions until she died. Two patients transplanted in first remission are in complete remission after 58 and 30 weeks, respectively.

Table 4. Haematological reconstitution

\begin{tabular}{lc}
\hline Parameter & \\
\hline $\begin{array}{l}\text { Engraftment } \\
\text { Discharge from hospital } \\
\text { after BMT }\end{array}$ & $5 / 5$ \\
$\begin{array}{l}\text { Time of last red-cell } \\
\text { transfusion }\end{array}$ & $4.5-9$ weeks \\
$\begin{array}{l}\text { Time of last platelet } \\
\quad \text { transfusion }\end{array}$ & $10-13$ weeks \\
$\begin{array}{l}\text { Time to reach } \\
\text { neutrophils }\end{array}$ & $8-12$ weeks \\
\end{tabular}

a Excluding relapse and patient FB; the latter reverted to myelodysplasia and had low platelet counts that required transfusions until her death. 


\section{Discussion}

The haematological recovery and lack of procedural mortality in the five patients transplanted strongly suggest that the cultured cells engrafted and that this technique can be reliably used for autologous BMT. The recovery of peripheral blood cells, and especially of platelets, was slower than after allogeneic transplantation, but prolonged thrombocytopenia has been observed after conventional autologous transplantation [7]. In this context, as one of the patients in this series shows, a history of myelodysplasia may be a contraindication for autologous transplant.

The altered balance between the leukaemic and normal populations in culture is likely to be responsible for the remission achieved in the first patient. However, the high leukaemic load existing in the patient at the time of the ablative therapy, prior to transplantation, made the eventual relapse not unexpected. It is probable that relapses after autologous and allogeneic BMT are usually due to leukaemic cells which remain in the host after the conditioning treatment preceding the transplant. Because of this, relapses are to be expected with the present conditioning regimes in at least $25 \%$ of patients transplanted in first remission of AML.

The results, although preliminary, are encouraging and allow us to consider the possibility of manipulating the cultures by regulatory molecules (colony-stimulating factors, interferons and others) which may induce differentiation of leukaemic cells [8] and favour the growth of normal haemopoietic progenitors. Experiments along these lines are in progress. In addition, the use of cultured bone marrow for autologous transplants in CML, poor-prognosis acute lymphoblastic leukaemia or in some patients with solid tumors are possible developments for the future.
Acknowledgements. This work is supported by the Cancer Research Campaign (CRC) and the Leukaemia Research Fund. T. M. Dexter is a Fellow of the CRC.

\section{References}

1. Dexter TM, Spooncer E, Simmons P, Allen TD (1984) Long-term marrow cultures: an overview of techniques and experience. In: Wright DG, Greenberger JJ (eds) Long-term bone marrow culture. Liss, New York, p 57

2. Spooncer E, Dexter TM (1983) Transplantation of long-term cultured bone marrow cells. Transplantation 35:624

3. Hays EF, Hale L (1982) Growth of normal hemopoietic cells in cultures of bone marrow from leukaemic mice. Eur J Cancer Clin Oncol $18: 413$

4. Coulumbel L, Kalousek DK, Eaves CS, Gupta CM, Eaves AC (1983) Long-term marrow culture reveals chromosomally normal hemopoietic progenitor cells in patients with $\mathrm{Ph}$ positive chronic myelogenous leukemia. $\mathrm{N}$ Engl J Med 306:1493

5. Eaves C, Coulumbel L, Duke I, Kalousek J, Cashman J, Eaves AC (1985) Maintenance of normal and abnormal hemopoietic cell populations in long-term cultures of CML and AML marrow cells. In: Cronkite EP, Dainiak N, McCaffrey RP, Palek J, Quesenberry PJ (eds) Hematopoietic stem cell physiology. Liss, New York, p 403

6. Chang J, Coutinho L, Morgenstern G, Scarffe JH, Deakin D, Harrison C, Testa NG, Dexter TM (1986) Reconstitution of haemopoietic system with autologous marrow taken during relapse of acute myeloblastic leukaemia and grown in long-term culture. Lancet I:294

7. Burnett AK, Tansey I, Watkins R, Alcorn M, Maharaj D, Singer CRJ, McKinnon S, McDonald GA (1984) Transplantation of unpurged autologous bone marrow in acute myeloid leukaemia in first remission. Lancet II:1068

8. Nicola NA, Metcalf D (1985) Binding of the differentiation - inducer GM-CSF to responsive, but not unresponsive leukaemia cell lines. Proc Natl Acad Sci USA 81:3765 